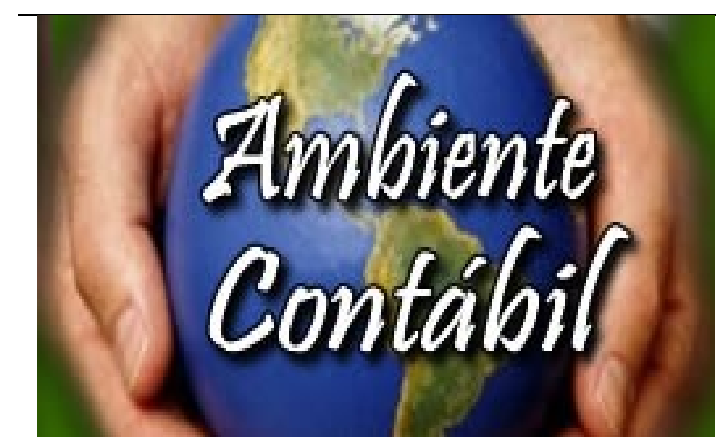

REVISTA AMBIENTE CONTÁBIL

Universidade Federal do Rio Grande do Norte ISSN 2176-9036

Vol. 14, n. 1, Jan/Jun, 2022

Sites: http://www.periodicos.ufrn.br/ambiente http://www.atena.org.br/revista/ojs-2.2.3-06/index.php/Ambiente

Article received on: 30 November 2020. Peer-reviewed on: 06 March 2021. Reformulated on: 08 April 2021. Evaluated by double blind review system.

DOI: $10.21680 / 2176-9036.2022 v 14 n 1$ ID27705

Socio environmental responsibility practices and organizational performance in public companies

Prácticas de responsabilidad socioambiental y desempeño organizacional en empresas que cotizan em bolsa

Práticas de responsabilidade socioambiental e o desempenho organizacional em companhias abertas

Authors

\title{
Naline Tres
}

Master's student in Accounting and Administration, area of Accounting and Management Controla t Universidade Comunitária da Região de Chapecó - UNOCHAPECÓ. Address: Rua John Kennedy, 2081 E, Passo dos Fortes district, Chapecó/SC, phone: (49) 9 8841-4168. Identifiers (ID):

ORCID: https://orcid.org/0000-0003-2419-7226

Lattes: http://lattes.cnpq.br/6787868546023365

E-mail: nalinetres@unochapeco.edu.br

\section{Claudia Dalla Porta}

Master in Accounting and Administration at Universidade Comunitária da Região de Chapecó - UNOCHAPECÓ. Address: Rua Nelson Catalan 93 D - Efapi, Chapecó - SC, Zip Code: 89809618. Phone number: (49) 9 9113-4812. Identifiers (ID):

ORCID: https://orcid.org/0000-0003-3366-6418

Lattes: http://lattes.cnpq.br/6572159735718347

E-mail: claudia.porta@unochapeco.edu.br

\section{Sady Mazzioni}

Doctor in Accounting Science and Administration at Universidade Regional de Blumenau (FURB), Professor of the Postgraduate Program in Accounting Science and Administration and the Undergraduate Program in Accounting Science at Universidade Comunitária da Região de Chapecó -UNOCHAPECÓ. Address: Servidão Anjo da Guarda, 295-D - Efapi, Chapecó - SC, Zip Code:89809-900. Phone number: (49) 3323-1868 / (49) 99928-9520. Identifiers (ID): 
ORCID: https://orcid.org/0000-0002-8976-6699

Research Gate: https://www.researchgate.net/profile/Sady_Mazzioni

Academy: https://independent.academia.edu/SadyMazzioni

Google Citations: ttps://scholar.google.com.br/citations?user=xmbXEagAAAAJ\&amp;hl=enBR

Lattes: http://lattes.cnpq.br/8383471282004653

E-mail:sady@unochapeco.edu.br

\section{Cristian Baú Dal Magro}

Doctor in Accounting Sciences and Administration at Universidade Regional de Blumenau (FURB), Professor of the Postgraduate Program in Accounting Sciences and Administration and of the Undergraduate Program in Accounting Sciences at Universidade Comunitária da Região de Chapecó -UNOCHAPECÓ. Address: Servidão Anjo da Guarda, 295-D - Efapi, Chapecó -SC, Zip Code:89809-900. Phone number: (49) 3346-3060 / (49) 99118-2003. Identifiers (ID):

ORCID: https://orcid.org/0000-0002-7609-5806

Research Gate: https://www.researchgate.net/lab/Cristian-Bau-Dal-Magro-Lab

Google Citations: https://scholar.google.com.br/citations?user=lU5aQu8AAAAJ\&amp;hl=enBR

Lattes: http://lattes.cnpq.br/7249286925737061

E-mail: crisbau@unochapeco.edu.br

\section{Daniela Di Domenico}

Master in Accounting Sciences at Universidade Regional de Blumenau (FURB), Professor of the Undergraduate Course in Accounting Sciences at Universidade Comunitária da Região de Chapecó -UNOCHAPECÓ. Address: Servidão Anjo da Guarda, 295-D - Efapi, Chapecó - SC, Zip Code: 89809-900. Phone number: (49) 3346-3060 / (49) 99118-2003. Identifiers (ID):

ORCID: https://orcid.org/0000-0003-3228-3669

Research Gate: https://www.researchgate.net/profile/Daniela_Di_Domenico

Lattes: http://lattes.cnpq.br/9241444291021630

E-mail: didomenico@unochapeco.edu.br

Abstract
Purpose: Analyze the relationship between socio-environmental responsibility practices in the economic and financial performance of companies listed in [B3].

Methodology: Social and environmental information found in the annual sustainability reports published in accordance with the GRI 4 (Global Reporting Initiative) standard were used. For economic performance, the metrics EBITDA and ROA were considered, while for financial performance, market-to-book and Tobin's Q were used, collected on the Economática ${ }^{\circledR}$ platform. Binomial logistic regression was used to evaluate 220 observations corresponding to the period from 2014 to 2018 .

Results: It was not possible to verify the relationship between the disclosure of socioenvironmental practices on economic performance, measured by the companies' accounting result variables. However, it suggests that there is a negative influence of the disclosure of 
information on socio-environmental practices on the financial performance measured by market variables.

Study Contributions: Despite the demands made by the set of stakeholders on companies for the practice of socioenvironmental actions, the market does not favorably recognize the organizational effort. The results point to indications that investors may consider organizational investments in socioenvironmental practices as undesirable.

Keywords: Corporate social responsibility, Performance, Publicly-held companies.

\section{Resumen}

Objetivo: Analizar la relación entre las prácticas de responsabilidad socioambiental en el desempeño de las empresas públicas enumeradas en [B3].

Metodología: Se utilizó la información social y ambiental encontrada en los informes anuales de sostenibilidad publicados de acuerdo con el estándar GRI 4 (Global Reporting Initiative). Para el desempeño económico se consideraron las métricas EBITDA y ROA, mientras que para el desempeño financiero se utilizaron market-to-book y Tobin's Q, recolectados en la plataforma Economática ${ }^{\circledR}$. Se utilizó regresión logística binomial para evaluar 220 observaciones correspondientes al período de 2014 a 2018.

Resultados: No fue posible verificar la relación entre la divulgación de prácticas socioambientales sobre el desempeño económico, medido por las variables de resultado contable de las empresas. Sin embargo, sugiere que existe una influencia negativa de la divulgación de información sobre prácticas socioambientales sobre el desempeño financiero medido por variables de mercado.

Contribuciones al estudio: A pesar de las demandas que el conjunto de stakeholders hace a las empresas para la práctica de acciones socioambientales, el mercado no reconoce favorablemente el esfuerzo organizacional. Los resultados apuntan a indicios de que los inversores pueden considerar indeseables las inversiones organizativas en prácticas socioambientales.

Palabras clave: Responsabilidad social empresarial, Desempeño, Empresas públicas.

\section{Resumo}

Objetivo: Analisar a relação entre as práticas de responsabilidade socioambiental no desempenho das companhias abertas listadas na [B3].

Metodologia: Foram utilizadas informações sociais e ambientais encontradas nos relatórios anuais de sustentabilidade divulgados de acordo com o padrão GRI 4 (Global Reporting Initiative). Para o desempenho econômico considerou-se as métricas EBITDA e ROA, enquanto para o desempenho financeiro utilizou-se market-to-book e Q de Tobin, coletadas na plataforma Economática ${ }^{\circledR}$. Utilizou-se a regressão logística binomial para avaliar 220 observações correspondentes ao período de 2014 a 2018.

Resultados: Não foi possível constatar a relação entre a divulgação das práticas socioambientais sobre o desempenho econômico, mensurado pelas variáveis de resultado 
contábil das empresas. Contudo, sugere que exista influência negativa da divulgação de informações das práticas socioambientais no desempenho financeiro mensurado por variáveis de mercado.

Contribuições do Estudo: Apesar das exigências interpostas pelo conjunto dos stakeholders sobre as empresas para a prática de ações socioambientais, o mercado não reconhece de modo favorável o esforço organizacional. Os resultados apontam para indícios de que os investidores podem considerar os investimentos organizacionais em práticas socioambientais como indesejáveis.

Palavras-chave: Responsabilidade Social Corporativa, Desempenho, Companhias abertas.

\section{Introduction}

Corporate Social Responsibility (CSR) practices are positive and responsible attitudes adopted by companies towards their stakeholders, both internal (employees) and external (customers, suppliers, environment, and society in general) (Blasi, Caporin \& Fontini, 2018). CSR is linked with sustainable practices tied to business strategies, seeking to create competitive advantage at the three levels of sustainability: economic, social, and environmental (Martinez-Conesa, Soto-Acosta \& Palacios-Manzano, 2017).

CSR is a commitment that the company has with its stakeholders, working ethically, contributing to the economic development, caring for the environment and the community (Mior, 2001). In this sense, CSR has the union of economic, social and environmental aspects, so that in addition to generating profit for shareholders it can also have a look to the other stakeholders, for example the community, customers, suppliers, among others (Galant \& Cadez, 2017).

CSR determines the way in which the organization relates to its stakeholders, each with its own interests, forming strategies to embrace social, environmental, and economic causes, so as to contribute to a better environment around them (Famiyeh, 2017). Thus, CSR serves as a theoretical framework for social and environmental practices, i.e., companies that adopt CSR conducts also have commitments to social and environmental aspects (Garriga \& Melé, 2004).

The tripod of sustainability encompasses the economic, social and environmental pillars, suggesting that the organization can develop and grow economically, without forgetting the sustainability issues, with the commitment to exercise its activities responsibly (Elkington, 2012). The way in which the organization relates with its group of stakeholders (customers, suppliers and community), can influence its activities (Freeman \& Phillips, 2002) in such a way that a good relationship with these groups can contribute in the search for legitimacy. This legitimacy can be obtained through the dissemination of its practices in order to engage the community and attract partners for their actions (Silva \& Sancovschi, 2006; Machado \& Ott, 2015).

Accounting can be an important tool in the context of sustainability, through which it is possible to generate information regarding the tripod of sustainability (economic, social and environmental), establish performance measures, disclose information for accountability to stakeholders, and make decisions in an ethical and responsible manner (Kocollari, 2015; Bebbington, Russel \& Thomson, 2017). 
Previous studies have linked the use of sustainable practices with the economicfinancial performance of companies and found that companies can perform well by adhering to socially and environmentally responsible practices (Choi, Kwak \& Choe, 2010; Tang, Hull \& Rotherberg, 2012; Raza, Ilyas, Rauf \& Qamar, 2012; Carrijo \& Malaquias, 2012), such that CSR does not exclude the fact that the organization adds economic-financial value (Carroll, 1979). Works such as those by Baldini, Maso, Liberatore, Mazzi and Terzani (2018) and Martínez-Ferrero, Garcia-Sanchez and Cuadrado-Ballesteros (2015) find positive results between this relationship of disclosure and performance.

In contrast, there are studies that consider a certain lack of clarity in the relationship between the disclosure of sustainability reports with the companies' performance; other studies point out that CSR does not influence the economic-financial performance; while some studies found negative influences regarding the performance of companies (Braga, Oliveira \& Salotti, 2009; Afonso, Fernandes \& Monte, 2012; Michelon, Pilonato \& Ricceri, 2015; Vergini, Turra, Jacomossi \& Hein, 2015; Gonçalves, Anjos \& Freitas, 2019). According to Michelon et al. (2015), the disclosure of sustainability reports can be a symbolic practice that generates additional cost to the companies that do it, compromising performance.

Given the inconclusive results, it becomes relevant to continue investigating the topic. Thus, the study is guided by the following research question: what is the relationship between social and environmental responsibility practices and the performance of publicly traded companies listed on the [B3]? The study aims to analyze the relationship between social and environmental responsibility practices in the performance of publicly traded companies listed on the [B3] stock exchange.

The accountability of organizations to their stakeholders helps them to become more sustainable, ethical, and transparent (Kocollari, 2015). The reasons why companies have adhered to CSR practices can be diverse: believing in a better world and society; meeting certain legislations; obtaining future gains (Galant \& Cadez, 2017).

This study aims to demonstrate to stakeholders whether socio-environmental practices can bring benefits to the economic and financial performance of companies, or only cause costs. In addition, it aims to understand whether the market has a favorable or unfavorable perception towards socio-environmental actions, understanding that investors are interested in the return of their capital.

Thus, the study is justified by the importance of disclosing information concerning sustainable practices, which can produce greater legitimacy before stakeholders and ensure the perpetuity of the company's activities. The analysis of the relationship of socio-environmental practices with economic-financial performance aims to verify whether such practices are bringing economic and financial benefits to companies, making it possible to verify whether investors are taking disclosure into account, considering that previous studies present both positive relationships and negative and neutral relationships, so that the theme can still be explored.

\section{Literature Review}

The literature review is structured in three subsections: social and environmental responsibility; organizational performance; and, the interrelationship between social and environmental responsibility and organizational performance. 


\subsection{Socio-environmental Responsibility}

The "standard story" of business, tied to generating economic value, is no longer sufficient, since it is necessary to think about the social effects of the actions of organizations in order to unite social and economic aspects (Freeman \& Phillips, 2002). The success of an organization also depends on how it relates to the environment in which it operates, as well as its key groups: customers, suppliers, community, among others that may influence its activities (Freeman \& Phillips, 2002). A close channel of relationship with customers can add value to organizations (Servaes \& Tomayo, 2013).

Socio-environmental responsibility practices began in the United States in the twentieth century, with roots in religious thoughts in which certain principles were applied in organizational activities, such as: the principle of charity (people who owned more goods helped those who had less); and the principle of stewardship (the economic assets of companies should also be used for the good of the community). From this, philanthropy in large companies emerged (Busch \& Ribeiro, 2009).

CSR practices have become part of business practice in recent decades, in such a way that companies have dedicated themselves to demonstrating the importance of socioenvironmental activities in their annual reports (Servaes \& Tamayo, 2013). Environmental disclosure is a way to obtain or regain social legitimacy before society through the popularization of their practices, to demonstrate the form of management and to obtain partners in the development of actions (Machado \& Ott, 2015; Silva \& Sancovschi, 2006).

Similarly, CSR goes beyond the legal obligations that a company needs to fulfill, it is part of the organization's strategy (Choi et al., 2010). Busch (2008) refers to social and environmental responsibility as the act of being legitimate in business operations in the face of society's social and environmental demands. Its characteristics are based on attitudes of moral and ethical values with the major objective of reducing the impact that companies cause on the environment and compensating the society in which they operate.

Therefore, socio-environmental responsibility refers to the position that the company has in relation to the environment in which it operates, assessing the impact it causes to the community in which it is installed. Sustainable practices help the company to fulfill its commitments to the environment, aiming to strengthen the image transmitted to its stakeholders (Oliveira, Portella, Ferreira \& Borba, 2016).

Socio-environmental responsibility goes beyond the concept of being a set of practices that aim for social and environmental good on a voluntary basis. It is the adoption of practices that bring benefits to the environment and society where it is installed, based on projects that support the local community, waste reduction campaigns and the reuse of natural resources (Di Domenico, Mazzioni, Gubiani, Kronbauer \& Vilani, 2015). Organizations with responsible conduct generate satisfaction to the society that compensates them with good relationships and loyalty (Busch \& Ribeiro, 2009).

\subsection{Organizational Performance}

All organizations aim to control their business, and to do this, they need to compare the established objectives with the results achieved. This analysis is called organizational performance and it serves to measure the company's ability to continue and survive in the market, considering the results against the changes and the need to readjust the objectives. For this analysis to occur it is necessary to measure, control and evaluate the results, as well as some aspects of the organization, such as its particularities, considering the tangible aspects 
(financial) and the intangible (non-financial), relating the operational objectives to the strategic ones, aiming to idealize the general objectives of the organization (Lizote, Alves, Verdinelli \& Terres, 2017).

Competition for market, customers, inputs, and capital makes organizational performance fundamental to managing organizations (Richard, Devinney, Yip \& Johnson, 2009), making it a recurring topic in the management field and in the research field (Venkatraman \& Ramanujam, 1986).

The strategic management process comprises drawing a mission, from which its possible to develop efforts in the business and a competitive strategy, monitoring performance to refine the strategy or its implementation (Olson \& Slater, 2002).

Organizational performance is composed of several variables and competitive advantage is an insufficient condition for performance. In relation to financial performance, competitive advantage may not result in profitability, although many analyses are restricted to observing the effects on profitability (Brito \& Brito, 2012).

In this context, performance is conceptualized in organizational theory as an indicator of efficiency, while in the field of organizational research, it becomes a dependent variable (Carvalho, 2014).

\subsection{Social-environmental Responsibility and Organizational Performance}

The increasing participation of companies in socio-environmental causes is observed as an important factor in the financial market. In this sense, companies can benefit financially by adopting socio-environmental engagement strategies (Tang et al., 2012). The findings of Lima, Mello, Pessoa, Cabral, Rebouças, and Santos (2013) demonstrated through factor analysis and multiple linear regression, that social and environmental investments have a positive relationship in economic and financial indicators. The research was conducted with data from 40 companies in the energy sector in 2011.

Similarly, the study by Raza et al. (2012) examined the relationship between CSR and corporate performance and found evidence of the positive influence of CSR on corporate financial performance. The study was based on content analysis from 1972 to 2012. Marques and Teixeira (2008) found evidence in empirical studies that confirm a positive relationship between social responsibility and organizational performance. In most studies associated with stakeholder theory, in which the social impact hypothesis is justifying a relationship between social performance and economic performance.

In Brazil, Baldini et al. (2018) and Gomes (2015) indicated positive results between the relationship of disclosing sustainable practices and performance. Baldini et al. (2018) analyzed 14,174 countries over the period from 2005 to 2012 and reported that the disclosure of social and environmental practices can vary depending on the individual characteristics of each organization and the particular aspects of each country, such as political system, labor system, and cultural system. Gomes (2015) observed the relationship of economic, social and environmental disclosure and the performance of 93 publicly traded companies listed on [B3] in the year 2010, having evidence of a positive relationship with these variables.

Martínez-Ferrero et al. (2015) investigated a sample of 747 non-financial companies from 25 countries, comprising the period of eight years (2002 to 2010), in order to analyze the relationship between the quality of financial reporting and the quality of CSR information. The results showed that companies with high quality financial disclosure tend to publish a high quality sustainability report. 
On the other hand, negative relations are also demonstrated between CSR and economic performance, whose justifications found in the literature are directed to the hypotheses of availability of resources, exchange and opportunism of management, pointed as negative (Marques \& Teixeira, 2008). An example is the study Vergini et al. (2015), in which the variables analyzed point out a negative relationship between social and economic indicators.

The findings of Afonso et al. (2012) have indicated that in the companies researched, those that have a good corporate social performance are not the same as those with better economic performance indicators. However, they emphasize the importance of following a path that unites the two performances, in order to ensure more sustainability to organizations.

The study by Blasi et al. (2018) analyzed the relationship between CSR macro categories and organizational performance of companies by economic sector. The authors indicate that companies have more actions linked to social responsibility in the macro categories of their interest or to meet regulatory requirements. In addition, they found divergent results according to economic sector and CSR macro categories, evidencing positive and negative relationships between CSR and return on assets.

Michelon et al. (2015) reported that sustainability disclosure in companies may be seen only as a symbolic practice and that it generates cost, compromising performance. Braga et al. (2009) found no relationship between performance and sustainability reporting disclosure in Brazilian companies. The study by Gonçalves et al. (2019) analyzed the influence of CSR on the performance of companies listed on [B3] from 2013 to 2017 and found no improvement in company performance.

In view of the divergences pointed out in the studies found, the second research hypothesis is presented:

H1: Corporate social and environmental practices are related to the organizational performance of publicly traded companies listed on [B3].

\section{Methodological Procedures}

The procedures used allow characterizing the research as descriptive, with documentary analysis and quantitative approach. To conduct the study, sustainability reports were analyzed in the GRI 4 model of the Global Reporting Initiative of publicly traded companies listed on [B3], from the years 2014 to 2018, found in the "Report or Explain" on the website of [B3].

As proposed by Galant and Cadez (2017) binary variables were used to measure the items evidenced in the reports (assigning 1 for items evidenced in sustainability reports and 0 for items not evidenced). The sample investigated was constituted as shown in Table 1.

\section{Table 1}

Sample Definition

\begin{tabular}{c|c|c|c|c}
\hline \multicolumn{1}{c|}{ Description of sample composition } & $\mathbf{2 0 1 5}$ & $\mathbf{2 0 1 6}$ & $\mathbf{2 0 1 7}$ & $\mathbf{2 0 1 8}$ \\
\hline $\begin{array}{l}\text { Companies that published a sustainability report } \\
\text { according to the GRI 4 standard (except financials) }\end{array}$ & 111 & 73 & 73 & 86 \\
$\begin{array}{c}\text { (-) Companies without socio-environmental information } \\
\text { Total }\end{array}$ & 43 & 22 & 26 & 32 \\
\hline
\end{tabular}

Source: survey data. 
According to Table 1, the sample consisted of 220 observations covering the period of 4 years. It is noteworthy that the year 2015 comprised the largest number of observations.

Based on the analysis of the socio-environmental evidencing in the sustainability reports, and based on the information presented in the sustainability reports, an index was generated to represent the Evidencing variable, so as to analyze its relationship with the economic-financial performance indicators: EBTIDA, ROA, MTB, and Tobin's Q.

The economic and financial data were collected from the Economática ${ }^{\circledR}$ database. The economic and financial data were divided into economic performance (EBTIDA and ROA) and financial performance (MTB and Tobin's Q), for which the median of each indicator was established, using the binary variable 1 for companies with performance above and/or equal to the median and 0 for companies with performance below the median.

Table 2 presents the research construct, indicating the variables used, the metrics, the data sources, and the background authors.

Table 2

Research Construct

\begin{tabular}{|c|c|c|c|}
\hline Variable & Metric & Data Source & Theoretical basis \\
\hline \multicolumn{4}{|c|}{ Dependent Variables } \\
\hline $\begin{array}{c}\text { Return on } \\
\text { Assets }=\text { ROA }\end{array}$ & $\begin{array}{l}\text { Dummy equal to } 1 \text { for firms with } \\
\text { ROA } \geq \text { than the median and } 0 \text { for } \\
\text { firms with } \mathrm{ROA}<\text { than the median }\end{array}$ & Economática & $\begin{array}{c}\text { Afonso, Fernandes and Monte } \\
\text { (2012); Tang, Hull and } \\
\text { Rotherberg (2012); Raza et al. } \\
\text { (2012). }\end{array}$ \\
\hline $\begin{array}{l}\text { Market to Book } \\
\quad=\text { MTB }\end{array}$ & $\begin{array}{l}\text { Dummy equal to } 1 \text { for firms with } \\
\text { MTB } \geq \text { than the median and } 0 \text { for } \\
\text { firms with MTB }<\text { than the median. }\end{array}$ & Economática & $\begin{array}{c}\text { Almeida; Lopes; Corrar (2013), } \\
\text { Vilhena and Camargos (2015), } \\
\text { Freguete; Nossa; Funchal } \\
\text { (2015). }\end{array}$ \\
\hline $\begin{array}{l}\text { Tobin's Q }= \\
\text { QoT }\end{array}$ & $\begin{array}{l}\text { Dummy equal to } 1 \text { for firms with } \\
\text { QoT } \geq \text { than the median and } 0 \text { for } \\
\text { QoT }<\text { than the median. }\end{array}$ & Economática & $\begin{array}{c}\text { De Sousa; De Pinho (2007), } \\
\text { Vilhena and Camargos (2015), } \\
\text { Machado Junior, Ribeiro, } \\
\text { Mazzali, Bazanini and Pereira } \\
\text { (2017) }\end{array}$ \\
\hline $\begin{array}{l}\text { Accounting } \\
\text { performance }= \\
(\mathrm{DESECON})\end{array}$ & \multicolumn{3}{|c|}{$\begin{array}{l}\text { Dummy equal to } 1 \text { for firms with EBITDA and ROA } \geq \text { than the median and } 0 \text { for firms } \\
\text { with EBITDA and ROA }<\text { than the median. }\end{array}$} \\
\hline $\begin{array}{c}\text { Market } \\
\text { performance }= \\
(\mathrm{DESFINAN})\end{array}$ & \multicolumn{3}{|c|}{$\begin{array}{l}\text { Dummy equal to } 1 \text { for firms with MTB and QoT } \geq \text { than the median and } 0 \text { for firms with } \\
\qquad \text { MTB and QoT }<\text { than the median. }\end{array}$} \\
\hline \multicolumn{4}{|c|}{ Independent Variables } \\
\hline $\begin{array}{l}\text { Environmental } \\
\text { disclosure }= \\
\text { Evidence }\end{array}$ & $\begin{array}{c}\text { Sum of the number of items of } \\
\text { compliance with the disclosure of } \\
\text { social and environmental practices } \\
\text { in the GRI standard of company } i \text { in } \\
\text { year t- } 1 \text {. }\end{array}$ & $\begin{array}{l}\text { Sustainability } \\
\text { Report }\end{array}$ & $\begin{array}{l}\text { Choi et al. (2010), Afonso, } \\
\text { Fernandes and Monte (2012), } \\
\text { Tang, Hull and Rotherberg } \\
\text { (2012) Raza et al. }(2012)\end{array}$ \\
\hline \multicolumn{4}{|c|}{ Control Variables } \\
\hline $\begin{array}{l}\text { Company size }= \\
\text { TAM }\end{array}$ & Natural logarithm of Total Assets & Economática & $\begin{array}{c}\text { Choi et al. (2010), Carrijo and } \\
\text { Malaquias (2012), Machado et } \\
\text { al. (2017). }\end{array}$ \\
\hline $\begin{array}{c}\text { Degree of } \\
\text { Immobilization } \\
=\text { GIM }\end{array}$ & Fixed Assets/Total Assets & Economática & $\begin{array}{l}\text { Iudícibus (2007), Matarazzo } \\
\text { (2010), Machado et al. (2017) }\end{array}$ \\
\hline $\begin{array}{l}\text { Sales growth = } \\
\text { Cresc_vend }\end{array}$ & $\begin{array}{l}\text { (Current Revenue - Previous } \\
\text { Revenue) / Previous Revenue }\end{array}$ & Economática & $\begin{array}{l}\text { Cowling (2004), Serrasqueiro, } \\
\text { Nunes and Sequeira (2007), }\end{array}$ \\
\hline
\end{tabular}




\begin{tabular}{c|c|c|c}
\hline & & & $\begin{array}{c}\text { Jang and Park (2011), Nakano } \\
\text { and Kim (2011) }\end{array}$ \\
\hline $\begin{array}{c}\text { Financial } \\
\text { Leverage }=\end{array}$ & Return on Equity / Return on Assets & Economática & $\begin{array}{c}\text { Flannery; Rangan (2006), Assaf } \\
\text { Neto and Lima (2011), } \\
\text { Mantovani and Santos (2015), } \\
\text { Tsuruta (2017). }\end{array}$ \\
\hline $\begin{array}{c}\text { Audit }= \\
\text { Big Four }\end{array}$ & $\begin{array}{c}\text { Dummy equal to 1 for companies } \\
\text { with Big Four auditing and 0 } \\
\text { otherwise. }\end{array}$ & $\begin{array}{c}\text { Management } \\
\text { Report }\end{array}$ & $\begin{array}{c}\text { Palmrose (1986), Krishnan } \\
\text { (2003), Almeida and Almeida } \\
\text { (2009), Martinez (2008) }\end{array}$ \\
\hline $\begin{array}{c}\text { Board } \\
\text { Independence }=\end{array}$ & $\begin{array}{c}\text { Number of independent directors / } \\
\text { total number of directors }\end{array}$ & $\begin{array}{c}\text { Management } \\
\text { Report }\end{array}$ & $\begin{array}{c}\text { Bhagat and Black (1999), Leal; } \\
\text { Oliveira (2002), Jaggi, Leung } \\
\text { and Gul (2009) }\end{array}$ \\
\hline
\end{tabular}

Source: survey data.

In the aggregate models, the DESECON dummy variable was equal to 1 for companies that concurrently had EBITDA and ROA above and/or equal to the median, referring to economic performance. As for financial performance, the dummy variable DESFINAN was assigned equal to 1 for companies with MTB and QTB performance above and/or equal to the median, concomitantly.

Sustainability reports are not mandatory in Brazil and companies do not have a deadline for disclosure. Thus, reports can be released in any period within the year in which the economic and financial information is presented. Thus, the outdated data for social and environmental responsibility practices were used.

Additionally, with respect to control variables, the research of Machado et al. (2017) showed that capital structure positively influences performance. On the other hand, Vilhena and Camargos (2015) pointed out that the size of the organization also influences performance.

The Degree of Fixed Assets, according to Iudícibus (2007), portrays how much of one's own resources are invested in fixed assets or that are not in rotation. In other words, companies with greater permanent assets have more guarantees in a liquidation or bankruptcy situation, for instance, and they can recover the value of this asset (Silva, 2013). According to Souza and Macedo (2009), the higher this index, the better the company's performance.

Klomp and Van Leeuwen (2001) and Cho and Pucik (2005) assert that innovative companies with better performance have more significant sales ratios. Financial leverage, on the other hand, refers to the possibility of gains for the partners with the use of debt, that is, the use of third-party capital (Marschner, Dutra \& Ceretta, 2019). The study by Vieira, de Souza Nogueira, da Cunha Moreira, Costa, and Santos (2019) signals that financial leverage has an influence on firm performance.

Companies that have audits performed by Big Four firms are viewed with more credibility by their stakeholders, due to the higher quality of the services received. Krishnan (2003) and Palmrose (1986), differentiate the Big Four by their greater degree of expertise, experiences in all sectors and countries of the world that enhance the techniques used by auditors. Collin, Smith, Umans, Broberg and Tagesson (2013) report that organizations that have a Big Four as their audit firm tend to have increased monitoring of their controls and greater expertise of the auditors, which leads to better performance.

Regarding the independence of the board of directors, Andrade, Salazar, Calegário, and Silva (2009) report in their study that, based on the sample of companies analyzed, most companies had a board with a higher number of independent directors, as recommended by good governance practices. 
To answer the research hypothesis, the statistical technique of logistic regression was used. To meet the model assumptions, the tests for normality, multicollinearity, homoscedasticity and autocorrelation of the residues were used (Cunha \& Carlos, 2007).

\section{Results and Analysis}

In the results analysis section the tables referring to the data generated are presented, which comprise the frequency statistics of the dummy (binary) variables, descriptive statistics and the binary logistic regression of the study variables. Table 3 shows the frequency statistics of the dummy variables.

\section{Table 3}

Frequency statistics of binary variables

\begin{tabular}{c|c|c|c|c|c}
\hline Variables & Frequency & Percentage & Variables & Frequency & Percentage \\
\hline EBTIDA (0) & 110 & 50 & QoT (0) & 110 & 50 \\
EBTIDA (1) & 110 & 50 & QoT (1) & 110 & 50 \\
ROA (0) & 110 & 50 & DESMERC (0) & 132 & 60 \\
ROA (1) & 110 & 50 & DESMERC (1) & 88 & 40 \\
DESCONT (0) & 144 & 65,5 & BIGFOUR (0) & 43 & 19,5 \\
DESCONT (1) & 76 & 34,5 & BIGFOUR (1) & 177 & 80,5 \\
MTB (0) & 110 & 50 & & & \\
MTB (1) & 110 & 50 & & &
\end{tabular}

Source: Research data.

It is possible to observe that for the accounting performance variables EBTIDA and ROA the percentage was $50 \%$ for both frequencies for the two variables. For the DESCONT variable, in Dummy 0 the percentage was $65.5 \%$ of the companies and for Dummy $134.5 \%$ is observed, which represents the percentage of companies that had an accounting performance equal to or greater than the median.

In market performance, it is observed that MTB and QoT have percentages of $50 \%$ for Dummy 0 and 1, while the DESMERC variable has a percentage of $60 \%$ for Dummy 0 , that is, this is the percentage of companies in the sample that have the DESMERC variable below the median and $40 \%$ for Dummy 1 , this percentage is for companies that have the DESMERC above the median.

Regarding the big four audit, $19.5 \%$ of the companies are not audited by big four audit firms and $80.5 \%$ of the companies in the sample are audited by big four.

Table 4 presents the descriptive statistics for the quantitative variables.

Table 4

Descriptive statistics of the variables

\begin{tabular}{c|c|c|c|c|c}
\hline Variables & N & Minimum & Maximum & Average & Standard Deviation \\
\hline EBTIDA & 220 & -14.848 .128 & 108.522 .000 & $3.741 .141,65$ & 0,115846556 \\
ROA & 220 & $-1,449927$ & 0,220961 & $-0,00115802$ & 0,159664785 \\
MTB & 220 & $-16,071585$ & 53,438416 & 2,35179454 & 4,925526263 \\
QoT & 220 & 0,015992 & 4,13996 & 0,66588134 & 0,711567691 \\
Evidence & 220 & $4,17 \%$ & $95,83 \%$ & $35,44 \%$ & $17,34 \%$
\end{tabular}




\begin{tabular}{c|c|c|c|c|c} 
Ind_Cons & 220 & 0 & 100 & 25,959 & 23,6008 \\
Cresc_Vend & 220 & $-0,731805$ & 3,410905 & 0,09667466 & 0,359418222 \\
GIM & 220 & 0 & 0,753567 & 0,23274846 & 0,208365679 \\
Leverage & 220 & $-51,7$ & 741,1 & 9,13 & 65,9695 \\
TAM & 220 & 87.616 & 900.135 .000 & $39.816 .464,36$ & 1,56391
\end{tabular}

Source: Research data.

Table 4 comprises the descriptive statistics of the variables, in which initially it is possible to observe the EBTIDA data. On average the EBTIDA of the companies was R\$ $3,741,141.65$, the minimum was $\mathrm{R} \$-14,848,128$ and the maximum was $\mathrm{R} \$ 108,522,000$. For ROA the average was -0.00115802 for the companies in the sample analyzed, in which the minimum was -1.449927 and the maximum was 0.220961 .

For the MTB variable the average of the companies was 2.35179454, with the minimum of -16.071585 and the maximum for this variable being 53.438416. For the QoT variable, the average of the companies was 0.66588134 , with a minimum of 0.015992 and a maximum of 4.13996 .

Regarding socio-environmental disclosure. The average number of GRI items disclosed by companies is $35.44 \%$, with the minimum disclosure being $4.17 \%$ and the maximum $95.83 \%$. As far as board independence is concerned, the average number of independent board members in the companies is 25.959 , with a minimum of 0 and a maximum of 100 . The average sales growth of the companies in the sample was 0.09667466 , with a minimum of 0.731805 and a maximum of 3.410905 .

The GIM of the sample companies obtained an average of 0.23274846 , with a minimum of 0 and a maximum of 0.753567 . In relation to Financial Leverage the average of the companies was 9.13 , with a minimum of -51.7 and a maximum of 741.1 . For the TAM variable the average was $39,816,464.36$, the minimum of 87,616 and the maximum of $900,135,000$ of the companies in the sample.

To observe the relationship exercised by the independent variables in relation to the performance variables (dependent), the logistic regression method was used. For the analysis, the performance variables were segregated into economic and financial indicators. Table 5 presents the results in relation to the companies' economic performance.

\section{Table 5}

Binomial logistic regression of the relationship between social and environmental responsibility practices and economic performance

\begin{tabular}{l|c|c|c|c|c|c}
\hline \multirow{2}{*}{$\begin{array}{c}\text { Independent } \\
\text { variables }\end{array}$} & \multicolumn{2}{c|}{ EBTIDA (1) } & \multicolumn{2}{c}{ ROA (2) } & \multicolumn{2}{c}{ DESECON (3) } \\
\cline { 2 - 7 } & B & Sig. & B & Sig. & B & Sig. \\
\hline Evidence & 0,001 & 0,904 & $-0,007$ & 0,403 & $-0,001$ & 0,921 \\
\hline Big Four & 0,283 & 0,444 & 0,580 & 0,117 & 0,598 & 0,143 \\
\hline Ind_Cons & $-0,009$ & 0,137 & 0,000 & 0,939 & $-0,003$ & 0,592 \\
\hline Cresc_Vend & 0,739 & 0,128 & 0,605 & 0,183 & 0,588 & 0,173 \\
\hline GIM & 1,294 & $0,064 * *$ & $-0,359$ & 0,595 & 0,273 & 0,698 \\
\hline Leverage & 0,001 & 0,751 & $-0,006$ & 0,276 & $-0,006$ & 0,432 \\
\hline TAM & 0,132 & 0,179 & $-0,064$ & 0,505 & 0,018 & 0,856 \\
\hline Constant & $-2,534$ & $0,098 * *$ & 0,864 & 0,560 & $-0,398$ & 0,366 \\
\hline
\end{tabular}




\begin{tabular}{l|c|c|c}
\hline R-square & 0,076 & 0,052 &, 042 \\
\hline Chi-square & 12,998 & 8,725 & 6,764 \\
\hline Chi-square & 0,072 & 0,273 & 0,454 \\
\hline
\end{tabular}

* Significance at 5\% level and ** significance at $10 \%$ level

Source: Research data.

Table 5 presents the results for the economic indicators, being EBTIDA (model 1) and ROA (model 2), separately. Then, an aggregate indicator of economic performance was constituted (model 3), considering companies that had both indicators equal to or above the sample median. It is noticed that in none of the economic performance models evidencing showed a relationship, which demonstrates that the evidencing of socio-environmental responsibility practices is not related to the economic performance of the analyzed companies.

Regarding the independent variables, it was found that GIM showed influence only on EBTIDA, while the other independent variables (Big Four, Board independence, sales growth, financial leverage, and size) showed no relationship between the economic performance indicators.

Thus, the research corroborates the study of Afonso et al. (2012), whose findings indicated that companies with good socio-environmental performance are not the same as those with good economic performance. However, it failed to corroborate the study of Vergini et al. (2015), who found negative relationships between social and environmental performance and economic performance.

Freeman and Phillips (2002) emphasize the importance of organizations being concerned with the social impacts generated in the environment in which they operate, so as to unite social and economic aspects as a form of engagement with stakeholders (community, customers, suppliers, among others). However, the research findings show that the social and environmental actions promoted by the sample companies have not yet resulted in improved economic performance, a fact also identified in the research of Gonçalves et al. (2019).

Table 6 presents the results regarding financial performance.

Table 6

Logistic regression of the relationship between social and environmental responsibility practices and financial performance

\begin{tabular}{|c|c|c|c|c|c|c|}
\hline \multirow{2}{*}{$\begin{array}{c}\text { Independent } \\
\text { variables }\end{array}$} & \multicolumn{2}{|c|}{ MTB (1) } & \multicolumn{2}{|c|}{ QdT (2) } & \multicolumn{2}{|c|}{ DESFINAN (3) } \\
\hline & B & Sig. & B & Sig. & B & Sig. \\
\hline Evidence & $-0,020$ & $0,020 *$ & $-0,016$ & $0,055 * *$ & $-0,021$ & $0,019 *$ \\
\hline Big Four & 0,730 & $0,051 * *$ & 0,887 & $0,020^{*}$ & 1,396 & $0,001 *$ \\
\hline Ind_Cons & 0,003 & 0,599 & $-0,004$ & 0,555 & $-0,005$ & 0,427 \\
\hline Cresc_Vend & 0,192 & 0,627 & 0,524 & 0,248 & 0,151 & 0,705 \\
\hline GIM & 0,281 & 0,681 & 0,650 & 0,343 & 0,490 & 0,487 \\
\hline Leverage & $-0,001$ & 0,682 & $-0,011$ & 0,267 & $-0,009$ & 0,356 \\
\hline $\begin{array}{l}\text { TAM } \\
\text { Constant }\end{array}$ & $\begin{array}{r}0,089 \\
-1,457\end{array}$ & $\begin{array}{l}0,356 \\
0,327\end{array}$ & $\begin{array}{c}-0,106 \\
1,527\end{array}$ & $\begin{array}{l}0,274 \\
0,309\end{array}$ & $\begin{array}{c}0,007 \\
-0,882\end{array}$ & $\begin{array}{l}0,945 \\
0,566\end{array}$ \\
\hline R-square & \multicolumn{2}{|c|}{0,060} & \multicolumn{2}{|c|}{0,090} & \multicolumn{2}{|c|}{0,115} \\
\hline Chi-square & \multicolumn{2}{|c|}{10,170} & \multicolumn{2}{|c|}{15,298} & \multicolumn{2}{|c|}{19,627} \\
\hline Chi-square & \multicolumn{2}{|c|}{0,179} & \multicolumn{2}{|c|}{0,032} & \multicolumn{2}{|c|}{0,006} \\
\hline
\end{tabular}

* Significance at $5 \%$ level and ** significance at $10 \%$ level

Source: Research data. 
Table 6 shows the results for the market indicators (financial performance) used in the research, being MTB (model 1), QoT (model 2), and an aggregate index with the two variables (model 3 ). The findings suggest that social and environmental responsibility practices exert a negative relationship on MTB. It could be observed that companies with better performance in MTB showed less disclosure.

In as much as QoT is concerned, it is observed that environmental disclosure also exerts a negative relation in the indicator, i.e., the greater the company's disclosure, the worse its QoT. When analyzing the aggregate market indicator (model 3), presented in Table 6, the results were consistent with the individual models, reinforcing the negative effect of the disclosure of socioenvironmental practices on financial performance.

In general terms, the findings suggest that the market has seen socio-environmental responsibility practices as mechanisms that do not add value to the capital invested, due to the cost of implementation and maintenance involved. It is necessary for the company to equalize investments in socio-environmental responsibility, because society and shareholders seek practices in a company.

Thus, the research hypothesis can be partially confirmed by pointing out that CSR has a negative relationship with the financial performance of companies. The results contradict the assumption that the engagement of organizations in socio-environmental causes can improve their performance, given that it is an important factor for the financial market (Tang et al., 2012). The results are also contrary to the findings of Lima et al. (2013), Raza et al. (2012) and Marques and Teixeira (2008) who found positive relationships between social and environmental performance and financial performance.

Among possible factors for the negative relationship found between socioenvironmental disclosure and financial performance may be the analyzed period, in which the companies' performance was impacted by the difficult economic scenario, whose investment in socio-environmental practices was not converted into economic and financial performance. Another factor that must be considered is that investment in socio-environmental practices may take longer to be converted into performance, whose lag should be greater in the models used.

In relation to the control variables, it is observed that the auditing by the big four has a positive relationship with MTB, OdT and the aggregate model. Thus, the study points out that the Big Four audit firm has helped the companies in their valuation in the financial market, improving their performance.

The findings of this study, are in line with the studies of Christensen, Christensen, Kent and Stewart (2010) and Azim (2012), who demonstrated in their researches that the audit is an enhancing mechanism and that conveys greater transparency in the information of its financial reports, influencing its market value and the way shareholders view the company. Al Farooque, Van Zijl, Dunstan and Karim (2007), Lameira (2007) and Collin et al. (2013) also reinforce the assumption that companies audited by large auditing firms (Big Four) tend to receive more rigorous monitoring of their information by professionals of high quality and expertise, consequently increasing their performance.

The variables AC independence, sales growth, GIM, financial leverage and size showed no relationship with the QoT of the analyzed companies. ROA and EBITDA as an accounting measure and MTB and QoT as market measures are commonly used metrics for performance measurement. Galant and Cadez (2017) argue that improved economic performance can be reflected before accounting performance, however, in this study no positive relationships could be found in any of the performance indicators. 
Overall, the study reinforces the assumption found in Michelon et al. (2015), that the disclosure of sustainability reports can be a symbolic practice that generates additional cost to companies, compromising its performance

\section{Final Considerations}

The study analyzed the relationship between socio-environmental responsibility practices in the economic-financial performance of Brazilian companies, in the period from 2014 to 2018. For the proposed research, an analysis of sustainability reports prepared according to GRI 4 and economic and financial data extracted from the Economática ${ }^{\circledR}$ platform was conducted.

Research results show that there is no relationship between social and environmental practices disclosed by companies and economic performance, based on accounting metrics. Thus, it has been concluded that economic performance, measured by ROA, EBTIDA and the aggregate model of the two variables, was not significantly impacted by the disclosure of socioenvironmental practices by the companies researched. The other independent variables (auditing by the Big Four, board independence, sales growth, financial leverage, and size) also showed no relationship with the accounting performance of the surveyed companies. The only exception was the degree of immobilization, which proved to be significant in generating EBTIDA.

Regarding financial performance, analyzed by means of the market indicators MTB, QdT and the aggregate model of the two variables, the evidence points to a negative relationship of socio-environmental disclosure. Thus, companies with a higher volume of socioenvironmental practices showed lower (financial) market performance than their counterparts. In turn, companies audited by large auditing firms showed higher market performance than their counterparts.

The practical contribution of the study is the confirmation of previous studies that find no influence of CSR on firm performance (Michelon et al., 2015; Braga et al. , 2009; Gonçalves et al., 2019; Afonso et al., 2012; Vergini et al., 2015). However, the warning of Gonçalves et al. (2019) is worth, when pointing out that financial return cannot be the only motivation for which companies disclose information regarding CSR, as such disclosure is also related to the search for legitimacy before their stakeholders.

The results indicate the perception that investors mostly value actions that provide financial return on invested capital. In this sense, the results suggest that socio-environmental practices negatively affect financial performance (market), proving that investors recognize the additional costs involved in these actions. It is suggested that, despite the fact that many parties demand the involvement of companies with socio-environmental aspects, shareholders are still strongly interested in the financial aspect.

The results found indicate that in Brazil the socio-environmental practices carried out by companies are not yet considered so relevant by investors. This can be seen because the investment in socio-environmental practices has led to negative results for the companies that disclose the most (market performance) or even in relation to the accounting performance there is no relationship. Despite the stakeholders' demand for responsible socio-environmental actions, there is still no improvement in relation to the economic and financial performance of companies.

The research was limited to analyzing companies that disclosed their sustainability reports in the GRI 4 model. This limitation was established so that it would be possible to analyze equally the socio-environmental indicators disclosed by the companies. However, it 
must be taken into consideration that in Brazil the disclosure of the sustainability report is carried out on a voluntary basis, restricting the sample size and possibly influencing the results found.

However, this is a scenario that tends to change because companies are increasingly concerned about seeking legitimacy before their stakeholders (Machado \& Ott, 2015; Silva \& Sancovschi, 2006) and they have been concerned about the use and scarcity of resources. Thus, it is suggested for future research to use a longer period for the analysis of national reports, considering that several international studies indicate that social and environmental practices are related to the economic and financial performance of companies. Additionally, it can be considered a longer time lag for socio-environmental information compared to financial and economic ones.

\section{References}

Afonso, S., Fernandes, P. O., \& Monte, A. P. (2012). CSR of top Portuguese companies: relation between social performance and economic performance. World Academy of Science, Engineering and Technology, 6(6), 793-797.

Al Farooque, O., Van Zijl, T., Dunstan, K., \& Karim, A. W. (2007). Corporate governance in Bangladesh: Link between ownership and financial performance. Corporate governance: An international review, 15(6), 1453-1468. DOI: https://doi.org/10.1111/j.1467-

8683.2007.00657.x

Almeida, J. E. F. D., \& Almeida, J. C. G. D. (2009). Auditoria e earnings management: estudo empírico nas empresas abertas auditadas pelas Big Four e demais firmas de auditoria. Revista Contabilidade \& Finanças, 20(50), 62-74. DOI: http://dx.doi.org/10.1590/S151970772009000200005

Almeida, J. E. F. D., Lopes, A. B., \& Corrar, L. J. (2013). Gerenciamento de resultados para sustentar a expectativa do mercado de capitais: impactos no índice market-to-book. ASAAAdvances in Scientific and Applied Accounting, 4(1), 44-62.DOI:

https://doi.org/10.14392/asaa.2011040103

Andrade, L. P. D., Salazar, G. T., Calegário, C. L. L., \& Silva, S. S. (2009). Governança corporativa: uma análise da relação do conselho de administração com o valor de mercado e desempenho das empresas brasileiras. RA: Revista de administração mackenzie, 10(4), 4-31. DOI: http://dx.doi.org/10.1590/S1678-69712009000400002

Assaf Neto, A.; Lima, F. G. (2011). Curso De Administração Financeira (2a Ed.). São Paulo: Atlas.

Azim, M. I. (2012). Corporate governance mechanisms and their impact on company performance: A structural equation model analysis. Australian journal of management, 37(3), 481-505. DOI: https://doi.org/10.1177/0312896212451032 
Baldini, M., Dal Maso, L., Liberatore, G., Mazzi, F., \& Terzani, S. (2018). Role of countryand firm-level determinants in environmental, social, and governance disclosure. Journal of Business Ethics, 150(1), 79-98. DOI: https://doi.org/10.1007/s10551-016-3139-1

Bebbington, J., Russell, S., \& Thomson, I. (2017). Accounting and sustainable development: Reflections and propositions. Critical Perspectives on Accounting, 48, 21-34. DOI: https://doi.org/10.1016/j.cpa.2017.06.002

Bhagat, S., \& Black, B. (1999). The uncertain relationship between board composition and firm performance. The Business Lawyer, 921-963. DOI: https://doi.org/10.2139/ssrn.11417

Blasi, S., Caporin, M., \& Fontini, F. (2018). A multidimensional analysis of the relationship between corporate social responsibility and firms' economic performance. Ecological Economics, 147, 218-229. DOI: https://doi.org/10.1016/j.ecolecon.2018.01.014

Braga, J. P., Oliveira, J. R. S., \& Salotti, B. M. (2009). Determinants of Level of Environmental Disclosure in the financial statements of Brazilian Companies. Revista de Contabilidade da UFBA, 3(3), 81-95.

Brito, R. P. D., \& Brito, L. A. L. (2012). Vantagem Competitiva, criação de valor e seus efeitos sobre o desempenho. Revista de Administração de Empresas, 52(1), 70-84. DOI: http://dx.doi.org/10.1590/S0034-75902012000100006

Busch, S. E. (2008). Responsabilidade socioambiental de empresas fornecedoras de madeira certificada do tipo plantação. Universidade de São Paulo. São Paulo, SP, Brasil.

Busch, S. E. \& Ribeiro, H. (2009). Responsabilidade socioambiental empresarial: revisão da literatura sobre conceitos. INTERFACEHS - Revista de Gestão Integrada em Saúde do Trabalho e Meio Ambiente. 4(2).

Carroll, A.B (1979). Um modelo conceitual tridimensional de desempenho corporativo. Academy of Management Review, 4 (4), 497-505.

Carvalho, L. M. (2014). Educação corporativa e desempenho estratégico. Revista de Administração FACES Journal, 13(3), 67-85.

Carrijo, B. T., \& Malaquias, R. F. (2012). Relação entre responsabilidade social corporativa e indicadores de desempenho de empresas integrantes e não-integrantes do ISE 2010/2011. FACEF Pesquisa-Desenvolvimento e Gestão, 15(1).

Cho, H. J., \& Pucik, V. (2005). Relationship between innovativeness, quality, growth, profitability, and market value. Strategic management journal, 26(6), 555-575. DOI: https://doi.org/10.1002/smj.461

Choi, J. S., Kwak, Y. M., \& Choe, C. (2010). Corporate social responsibility and corporate financial performance: Evidence from Korea. Australian journal of management, 35(3), 291311. DOI: https://doi.org/10.1177/0312896210384681 
Christensen, J., Kent, P., \& Stewart, J. (2010). Corporate governance and company performance in Australia. Australian Accounting Review, 20(4), 372-386. DOI: https://doi.org/10.1111/j.1835-2561.2010.00108.x

Collin, S. O. Y., Smith, E., Umans, T., Broberg, P., \& Tagesson, T. (2013). Mechanisms of corporate governance going international. Baltic Journal of Management, 8(1), 79-101. DOI: https://doi.org/10.1108/17465261311291678

Cowling, M. (2004). The Growth-Profit Nexus. Small Business Economics, 22, 1-9. DOI: https://doi.org/10.1023/b:sbej.0000011568.42714.c9

Da Cunha, L. S., \& Carlos, A. (2007). Regressão linear múltipla. Análise multivariada: para os cursos de administração, ciências contábeis e economia. São Paulo: Atlas.

De Sousa, N. A., \& De Pinho, R. M. (2007). Uma Análise do Q de Tobin como Proxy para o Nível de Investimento da Firma.

Di Domenico, D., Mazzioni, S., Gubiani, C. A., Kronbauer, N. B., \& Vilani, L. (2015). Práticas de responsabilidade socioambiental nas empresas de capital aberto de Santa Catarina listadas na BM\&FBovespa. Revista Catarinense da Ciência Contábil, 14(42), 70-84. DOI: http://dx.doi.org/10.16930/2237-7662/rccc.v14n42p70-84

Elkington, J. (2012). A teoria dos três pilares - Triple bottom line. In: Elkington, J. Sustentabilidade, canibais com garfo e faca. (p.107-137) São Paulo: M. Books.

Famiyeh, S. (2017). Corporate social responsibility and firm's performance: empirical evidence. Social Responsibility Journal, 13(2), 390-406. DOI: https://doi.org/10.1108/SRJ04-2016-0049

Flannery, M. J., \& Rangan, K. P. (2006). Partial adjustment toward target capital structures. Journal of financial economics, 79(3), 469-506. DOI:

https://doi.org/10.1016/j.jfineco.2005.03.004

Freeman, R. E., \& Phillips, R. A. (2002). Stakeholder theory: A libertarian defense. Business ethics quarterly, 12(3), 331-349. DOI: https://doi.org/10.2307/3858020

Freguete, L. M., Nossa, V., \& Funchal, B. (2015). Responsabilidade social corporativa e desempenho financeiro das empresas brasileiras na crise de 2008. RAC-Revista de Administração Contemporânea, 19(2), 232-248. DOI: http://dx.doi.org/10.1590/19827849rac20151873

Galant, A., \& Cadez, S. (2017). Corporate social responsibility and financial performance relationship: a review of measurement approaches. Economic research-Ekonomska istraživanja, 30(1), 676-693. DOI: http://dx.doi.org/10.1080/1331677X.2017.1313122

Garriga, E., \& Melé, D. (2004). Corporate social responsibility theories: Mapping the territory. Journal of business ethics, 53(1), 51-71. 
Gomes, P. H. V. (2015). Fatores determinantes do disclosure voluntário sob o enfoque da sustentabilidade: uma análise das empresas dos países do BRIC. Revista de Gestão Social e Ambiental, 9(2), 70-87. DOI: https://doi.org/10.24857/rgsa.v9i2.1035

Gonçalves, H. S., dos Anjos, L. C. M., \& de Freitas, M. A. L. (2019). Relato integrado e desempenho financeiro das empresas listadas na B3. Race: Revista de Administração, Contabilidade e Economia, 18(2), 345-362.

Iudícibus, S. (2007) Análise de balanços: a análise da liquidez e do endividamento, a análise do giro, a análise da rentabilidade, a análise da alavancagem financeira, indicadores e análises especiais (análise de tesouraria de Fleuriet, EVA, DVA e EBITDA). (8. ed.) São Paulo: Atlas.

Jaggi, B., Leung, S., \& Gul, F. (2009). Family control, board independence and earnings management: Evidence based on Hong Kong firms. Journal of Accounting and Public Policy, 28(4), 281-300. DOI: https://doi.org/10.1016/j.jaccpubpol.2009.06.002

Jang, S. S., \& Park, K. (2011). Inter-relationship between firm growth and profitability. International Journal of Hospitality Management, 30(4), 1027-1035. DOI: https://doi.org/10.1016/j.ijhm.2011.03.009

Klomp, L., \& Van Leeuwen, G. (2001). Linking innovation and firm performance: a new approach. International Journal of the Economics of Business, 8(3), 343-364. DOI: https://doi.org/10.1080/13571510110079612

Kocollari, U. (2015). Contabilidade e controle: prestação de contas aos stakeholders. In: Laasch, O.; Conaway, R. N. Fundamentos da gestão responsável. (p.422-470) São Paulo: Cengage Learning.

Krishnan, G. V. (2003). Does Big 6 auditor industry expertise constrain earnings management? Accounting horizons, 17, 1-16. DOI: https://doi.org/10.2308/acch.2003.17.s$\underline{1.1}$

Lameira, V. J. (2007). Governança corporativa, risco e desempenho das companhias abertas brasileiras - uma análise do relacionamento entre as práticas de governança corporativa, $o$ risco e o desempenho das companhias abertas brasileiras. Tese (Doutorado em Administração) - Pontifícia Universidade Católica do Rio de Janeiro, Rio de Janeiro, RJ, Brasil. DOI: https://doi.org/10.17771/pucrio.acad.11174

Leal, R. P., \& De Oliveira, C. L. (2002). An evaluation of board practices in Brazil. Corporate Governance: The international journal of business in society, 2(3), 21-25. DOI: https://doi.org/10.1108/14720700210440053

Lima, A. D. A. P., Mello, L. C. O., Pessoa, M. N. M., Cabral, A. C. A., Rebouças, S. M. D. P., \& dos Santos, S. M. (2013). Investimentos socioambientais e o desempenho econômicofinanceiro das empresas: estudo empírico nas companhias abertas listadas na BM\&F Bovespa 
no setor de energia elétrica. Anais do Congresso Brasileiro de Custos-ABC, Uberlândia, MG, Brasil, 20.

Lizote, S. A., Alves, C. S. R., Verdinelli, M. A., \& Terres, J. C. (2017). Capital humano e sua relação com o desempenho organizacional em empresas prestadoras de serviços contábeis. Revista Catarinense da Ciência Contábil, 16(48). DOI: https://doi.org/10.16930/22377662/rccc.v16n48.2373

Machado, D. P., \& Ott, E. (2015). Estratégias de legitimação social empregadas na evidenciação ambiental: Um estudo a luz da Teoria da legitimidade. Revista Universo Contábil, 11(1), 136-156.

Machado Junior, C.; Ribeiro, D. M. N. M.; Mazzali, L.; Bazanini, R.; Pereira, R. S. (2017) Indicadores de governança e sustentabilidade de empresas brasileiras. Revista de Administração da Unimep, 15(3), 1-25.

Mantovani, M. H. C., \& dos Santos, J. O. (2015). Análise da relação entre alavancagem e rentabilidade dos bancos brasileiros listados na Bolsa de Valores de São Paulo no período de 2001 a 2010. REGE-Revista de Gestão, 22(4), 509-524. DOI: https://doi.org/10.5700/rege575

Marques, M., \& Teixeira, C. (2008). A responsabilidade social das empresas e o desempenho organizacional. Tékhne-Revista de Estudos Politécnicos, (10), 149-164.

Marschner, P. F., Dutra, V. R., \& Ceretta, P. S. (2019). Alavancagem financeira e rentabilidade nas empresas brasileiras listadas na B3. Revista Universo Contábil, 15(2).

Martinez, A. L. (2008). Quando o conselho de administração e a auditoria evitam earnings management? Evidências empíricas para empresas brasileiras. Anais do Congresso USP de Controladoria e Contabilidade, São Paulo, SP, Brasil, 8.

Martinez-Conesa, I., Soto-Acosta, P., \& Palacios-Manzano, M. (2017). Corporate social responsibility and its effect on innovation and firm performance: An empirical research in SMEs. Journal of cleaner production, 142, 2374-2383. DOI:

https://doi.org/10.1016/j.jclepro.2016.11.038

Martínez-Ferrero, J., Garcia-Sanchez, I. M., \& Cuadrado-Ballesteros, B. (2015). Effect of financial reporting quality on sustainability information disclosure. Corporate Social Responsibility and Environmental Management, 22(1), 45-64. DOI: https://doi.org/10.1002/csr.1330

Matarazzo, D. C. (2010). Análise financeira de balanços: Abordagem gerencial. (7. ed.). São Paulo: Atlas.

Michelon, G., Pilonato, S., \& Ricceri, F. (2015). CSR reporting practices and the quality of disclosure: An empirical analysis. Critical perspectives on accounting, 33, 59-78. DOI: https://doi.org/10.1016/j.cpa.2014.10.003 
Moir, L. (2001). What do we mean by corporate social responsibility?. Corporate Governance: The international journal of business in society, 1(2) https://doi.org/10.1108/EUM0000000005486

Nakano, A., \& Kim, D. (2011). Dynamics of growth and profitability: The case of Japanese manufacturing firms. Global Economic Review, 40(1), 67-81. DOI:

https://doi.org/10.1080/1226508x.2011.559329

Oliveira, M. D., Portella, A. R., Ferreira, D. D. M., \& Borba, J. A. (2016). Comunicação de Responsabilidade Socioambiental na Missão, Visão e Valores de Empresas da BM\&FBovespa; e da Fortune 500. Contabilidade, Gestão e Governança, 19(2), 192-210. DOI: https://doi.org/10.21714/1984-3925_2016v19n2a2

Olson, E. M., \& Slater, S. F. (2002). The balanced scorecard, competitive strategy, and performance. Business Horizons, 45(3), 11-16. DOI: https://doi.org/10.1016/s00076813(02)00198-2

Palmrose, Z. V. (1986). Audit fees and auditor size: Further evidence. Journal of accounting research, 97-110. DOI: https://doi.org/10.2307/2490806

Raza, A., Ilyas, M. I., Rauf, R., \& Qamar, R. (2012). Relationship between corporate social responsibility (CSR) and corporate financial performance (CFP): Literature review approach. Elixir Financial Management, 46, 8404-8409.

Richard, P. J., Devinney, T. M., Yip, G. S., \& Johnson, G. (2009). Measuring organizational performance: Towards methodological best practice. Journal of management, 35(3), 718-804. DOI: https://doi.org/10.1177/0149206308330560

Serrasqueiro, Z., Macas Nunes, P., \& Tiago Neves Sequeira, S. (2007). Firms' growth opportunities and profitability: a nonlinear relationship. Applied Financial Economics Letters, 3(6), 373-379. DOI: https://doi.org/10.1080/17446540701262827

Servaes, H., \& Tamayo, A. (2013). The impact of corporate social responsibility on firm value: The role of customer awareness. Management science, 59(5), 1045-1061. DOI: https://doi.org/10.1287/mnsc. 1120.1630

Silva, A.H.C; Sancovschi, M. (2006). Evidenciação social corporativa: estudo de caso da Empresa Petróleo Brasileiro AS. Anais do Congresso EnANPAD. Rio de Janeiro, RJ, Brasil, 15. DOI: https://doi.org/10.21446/scg_ufrj.vli1.13112

Tsuruta, D. (2017). Variance of firm performance and leverage of small businesses. Journal of Small Business Management, 55(3), 404-429. DOI: https://doi.org/10.1111/jsbm.12243

Tang, Z., Hull, C. E., \& Rothenberg, S. (2012). How corporate social responsibility engagement strategy moderates the CSR-financial performance relationship. Journal of Management Studies, 49(7), 1274-1303. DOI: https://doi.org/10.1111/j.14676486.2012.01068.x 
Venkatraman, N., \& Ramanujam, V. (1986). Measurement of business performance in strategy research: A comparison of approaches. Academy of management review, 11(4), 801814. DOI: https://doi.org/10.5465/amr.1986.4283976

Vergini, D. P., Turra, S., Jacomossi, F. A., \& Hein, N. (2015). Impacto da responsabilidade social no desempenho econômico financeiro das empresas brasileiras componentes do Dow Jones Sustainability Index. Revista Eletrônica em Gestão, Educação e Tecnologia Ambiental, 19(12), 879-898.

Vieira, K. V., de Souza Nogueira, T. C., da Cunha Moreira, M., Costa, G. Z., \& Santos, D. F. L. (2019). Alavancagem e desempenho financeiro: uma análise comparativa. Revista de Administração e Contabilidade da FAT, 8(3).

Vilhena, F. A. C. D., \& Camargos, M. A. (2015). Governança corporativa, criação de valor e desempenho econômico-financeiro: evidências do mercado brasileiro com dados em painel, 2005-2011. REGE - Revista de Gestão, 22(1), 77-96. DOI: https://doi.org/10.5700/rege552 